\title{
Kardiální manifestace myeloproliferativního onemocnění s eosinofilií
}

\author{
Ludmila Nováková1, Dana Mikulenková', Tomáš Paleček² \\ 'Ústar hematologie a krevni transfuze; 2ll. interní klinika kardiologie a angiologie, V̌seobecná fakultní nemocnice a 1. lékařská fakulta \\ Univerzity Karlovy, Praha, Česká republika
}

Osmadvacetiletá dosud zdravá žena byla doporučena k hematologickému vyšetření pro záchyt leukocytózy s anemií a trombocytopenií. Subjektivně uváděla přibližně měsíc trvající noční pocení, bez doprovodného zvýšení tělesné teploty či jiných známek infekce, dále opakované presynkopální stavy a nezávažné krvácivé projevy. Klinické vyšetření bylo bez pozoruhodností. V krevním obraze byla potvrzena leukocytóza $56 \times 10^{9} / 1$ s eosinofilií $16 \times 10^{9} / 1$ a vyplavováním granulocytárních prekursorů (obrázek 1), dále anemie s hodnotou hemoglobinu $94 \mathrm{~g} / \mathrm{l}$ a trombocytopenie $90 \times 10^{9} / 1$. Cytomorfologickým vyšetřením aspirátu kostní dřeně byla zjištěna hyperplastická granulopoeza se zmnoženými eosinofilními granulocyty (27\%) s atypickou morfologií a též mírně zmnožená atypická monocytopoéza (obrázek 2). Histologické vyšetření kostní dřeně bylo v souladu s obrazem myeloproliferativního onemocnění. Cytogenetickým vyšetřením (včetně FISH) byla prokázána translokace $\mathrm{t}(1,5)(\mathrm{q} 21.1, \mathrm{q} 33)$ zahrnující přestavbu PDGFRb, pouze molekulárně pak byl detekován fúzní gen

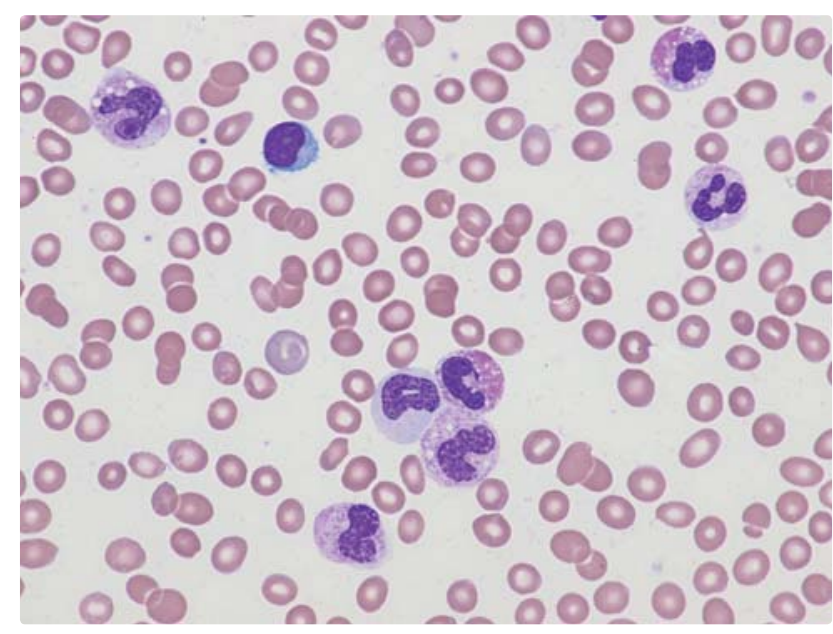

Obrázek 1 Nátěr periferní krve, panoptické barvení, zvětšení 1 000x: osm jaderných buněk, z toho jeden lymfocyt, čtyři atypické zralé neutrofily a dva patologické eosinofily (v pravém horním rohu a horní buňka ve čtveřici uprostřed)
FIP1L1/PDGFRa. Na základě výše uvedených nálezů byla stanovena diagnóza myeloproliferativního onemocnění s eosinofilií a abnormalitami PDGFRa a PDGFRb.

V rámci komplexního vyšetřovacího programu bylo též provedeno transthorakální echokardiografické vyšetření, při němž byla zjištěna nemobilní, homogenně echogenní patologická masa šiŕky cca $15 \mathrm{~mm}$, lokalizovaná v hrotové části levé komory, především infero- a posteroapikálně (obrázek $3 A, 3 B$ ); poruchy kinetiky levé komory včetně její hrotové části nebyly přítomny. Nález patologické masy byl se znalostí základního onemocnění uzavírán jako trombus v hrotu levé komory, reprezentující typické postižení srdce př̀i eosinofilii.

Cílená hematologická léčba byla započata krátkou úvodní cytoredukční terapií hydroxyureou, po níž byla s ohledem na př́itomnost fúzních genů zahájena specifická léčba tyrosinkinázovým inhibitorem imatinibem (Glivec) v dávce 100 mg/den. Hematologické odpovědi bylo dosaženo promptně, po šesti měsících léčby

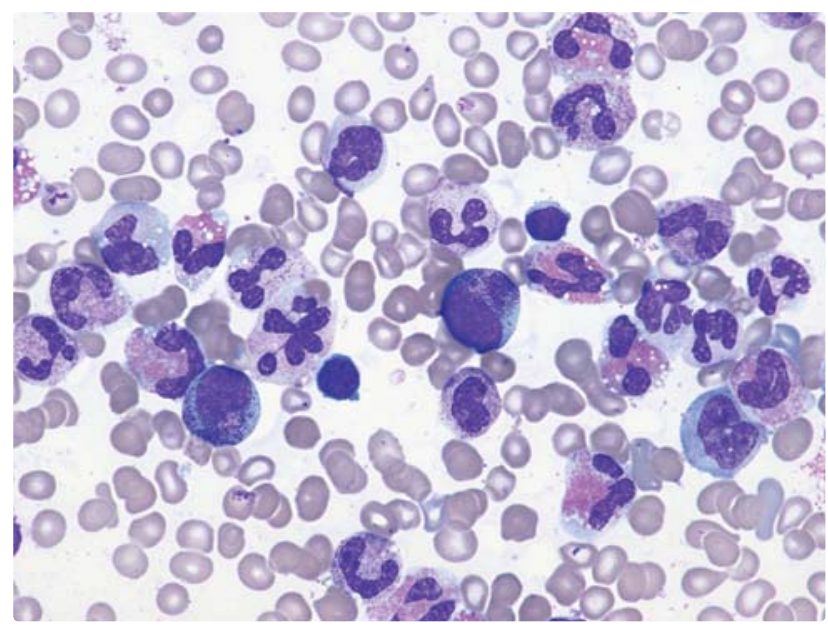

Obrázek 2 Nátěr aspirátu kostní dřeně, panoptické barvení, zvětšení 1 000x: převažují atypické buňky neutrofilní granulopoézy, dále př́tomny patologické zralé eosinofily, ojediněle zastiženy atypické monocyty s patologickou lobulizací jádra a lymfocyty

Adresa: MUDr. Tomáš Paleček, Ph.D., II. interní klinika kardiologie a angiologie, VFN a 1. LF UK, U Nemocnice 2, 12800 Praha 2, Česká republika, e-mail: tpalec@|f1.cuni.cz 
pak byla dokumentována kompletní odpověd’ cytogenetická i molekulární. Po celou dobu byla nemocná též léčena antikoagulačně nízkomolekulárním heparinem. Kontrolní echokardio-
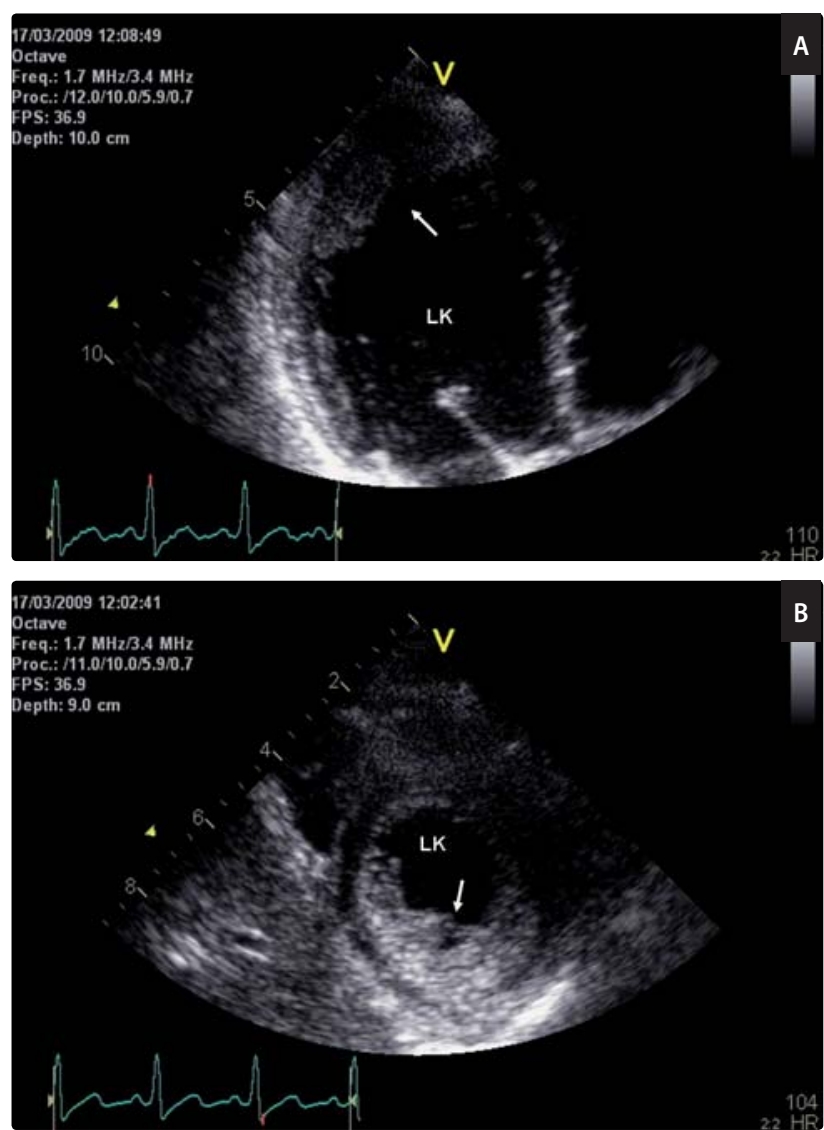

Obrázek 3 Transthorakální echokardiografické vyšetření při stanovení diagnózy: $v$ apikální projekci na dlouhou osu levé komory (A) a v parasternální projekci na krátkou osu levé komory (B) je v hrotu levé komory patrna velká echogenní patologická masa, představující trombus v typické lokalizaci pro hypereosinofilní syndrom (šipka) (LK = levá komora) grafické vyšetření s odstupem šesti měsíců prokázalo úplné vymizení patologické masy v oblasti hrotu levé komory (obrázek $4 A, 4 B)$.
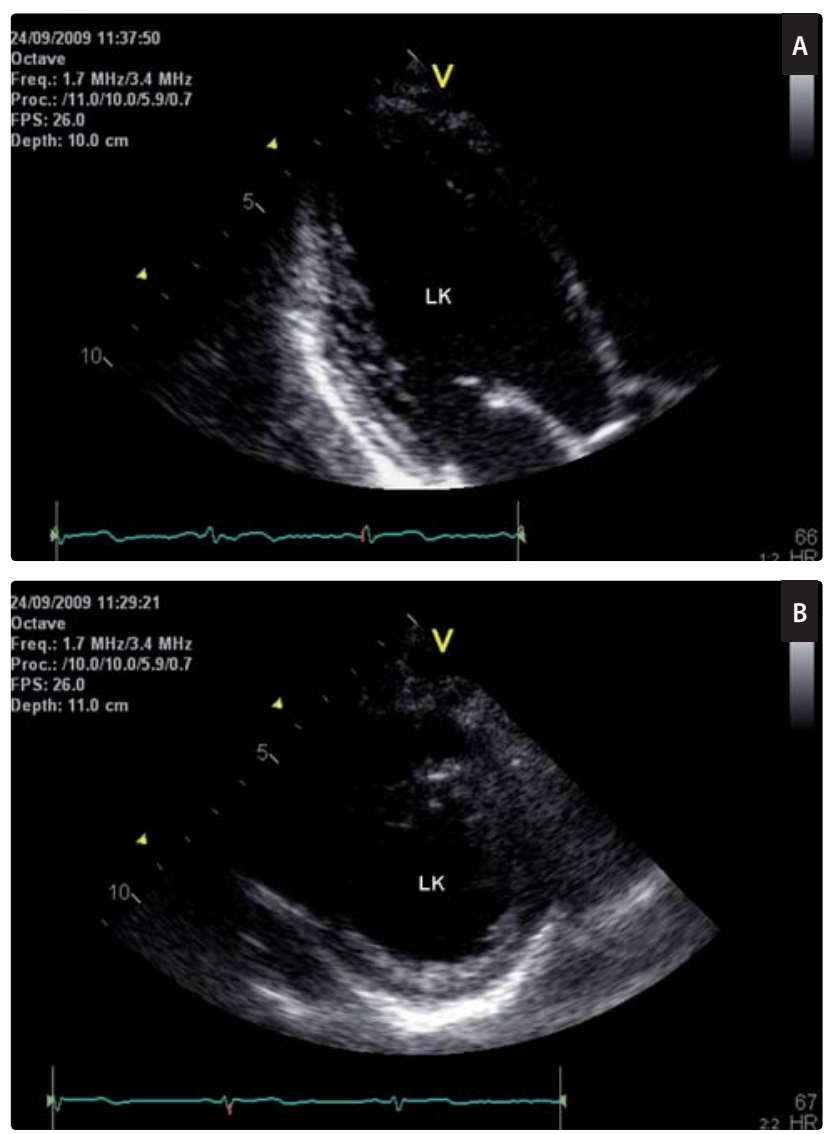

Obrázek 4 Transthorakální echokardiografické vyšetření po šesti měsících hematologické léčby: je patrno úplné vymizení patologické masy $v$ hrotu levé komory, a to jak v apikální projekci na dlouhou osu levé komory (A), tak i v parasternální projekci na krátkou osu levé komory (B) (LK = levá komora) 